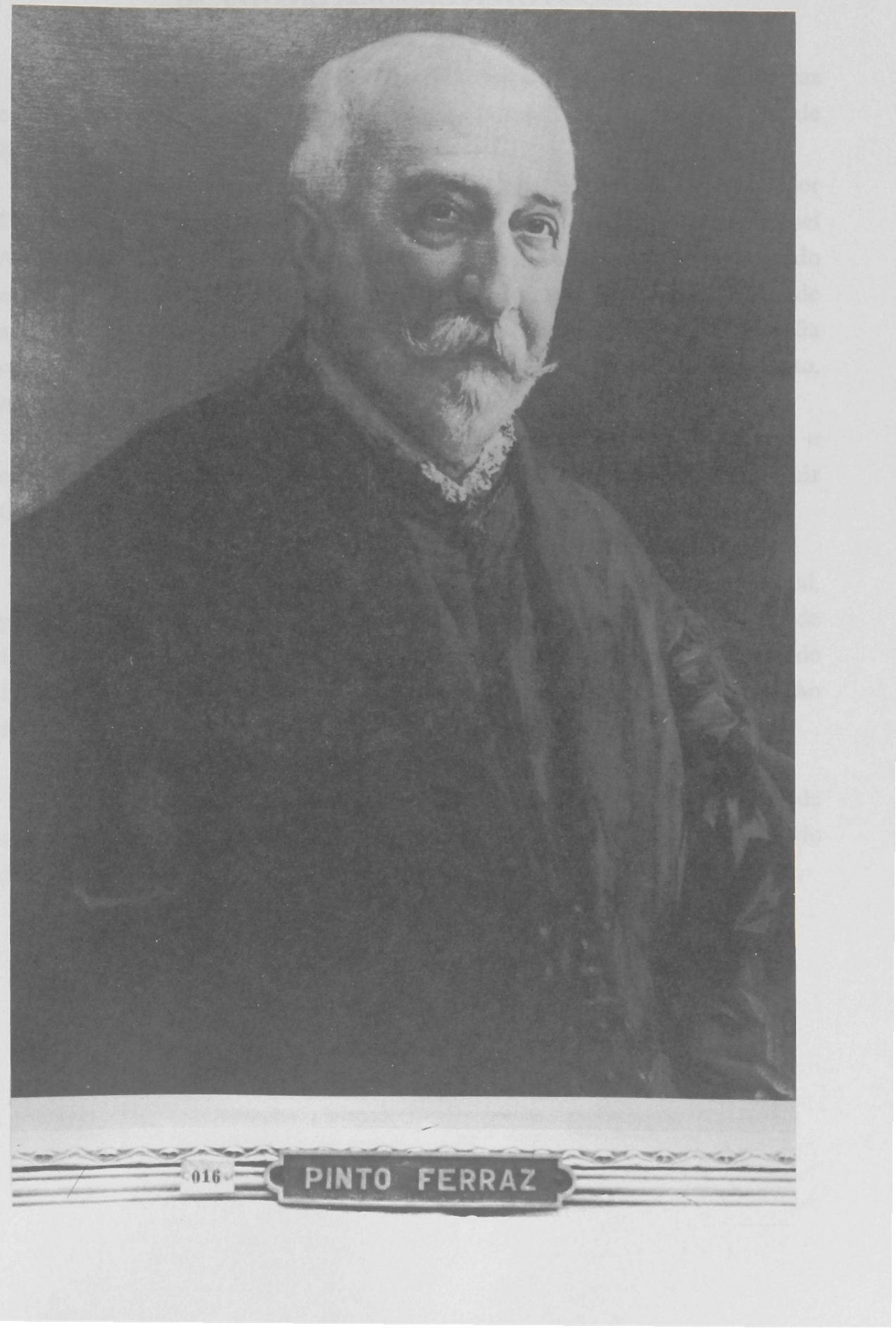





\section{Dr. ANTONIO JANUARIO PINTO FERRAZ \\ (1926-1930)}

Natural de Campinas. Filho do Comendador Antonio Pinto Ferraz e de D. Maria das Dores de Souza Camargo Ferraz, nasceu aos 2 de julho de 1851.

Estudou as primeiras letras no Colégio Bressane, dirigido por Francisco de Paula Bressane e, depois, com o seu parente, Padre Miguel Archanjo Ribeiro de Castro Camargo. De Campinas veio para São Paulo, tendo estudado no Liceu Alemão, do Dr. Carlos Bartt, grande matemático, onde aprimorou os seus estudos de língua inglesa, com o Dr. Morris. Estudou filosofia com o Dr. Galvão Bueno, freqüentou o Curso Anexo à Faculdade de Direito, nesta se matriculando em 1870 .

Bacharelando-se em 1874, passou a advogar em São Paulo, com o conselheiro Dr. Martim Francisco e, depois, com o Dr. Antonio Carlos e Luiz Gama, vindo a ser o seu escritório o mais afamado de seu tempo.

Defendeu teses em 1878 e foi unanimemente aprovado.

Lente catedrático de explicação sucinta de direito pátrio processual, primeira cadeira da segunda série de notariado, por decreto de 21 de março de 1891, tomou posse em 27 de abril seguinte. Por decreto de 7 de fevereiro de 1896, foi designado catedrático de direito civil, cadeira que regeu até 29 de julho de 1925, data em que, por decreto, foi posto em disponibilidade.

Desde 1904 foi eleito por diversas vezes senador estadual.

Nomeado diretor da Faculdade de Direito, por decreto de 19 de maio de 1926, presidiu, em 11 de agosto de 1927, as festas comemorativas do primeiro centenário da fundação dos cursos jurídicos de São Paulo e de Olinda. 